\title{
Evaluation of Agronomic Practices for Striga Controlling Management on Sorghum (Sorghum Bicolor L.) Crop Yield in Raya valley, Northern Ethiopia
}

\author{
Berhane Sibhatu $^{1 *} \quad$ Gebremeskel Gebrekorkos $^{1} \quad$ Hayelom Berhe $^{2} \quad$ Kasaye Abera ${ }^{1}$ \\ 1.Department of Field crops, Ethiopian Institute of Agricultural Research, Mekoni Agricultural Research Center, \\ P.O.Box, 71Maichew, Ethiopia \\ 2.Natural Resources Management Research Process, Ethiopian Institute of Agricultural Research, Mekoni \\ Agricultural Research Center, P.O. Box,71 Maichew, Ethiopia
}

\begin{abstract}
Striga hermonthica (Del.) Benth (Scrophulariacae), which is aggravated by the inherent low soil fertility, recurrent drought and continuous cereal monoculture, is one of the major production constraints in the sorghum growing regions of Ethiopia. Thus, an experiment on evaluation of agronomic practices for Striga controlling management on sorghum was conducted in 2016 and 2017 cropping seasons to determine the appropriate Striga controlling management practice under rain fed conditions. Treatments (T) comprised (T1) farmers' practice (no fertilizer and intercropping) as a control; (T2) compost (at10 ton ha $\left.{ }^{-1}\right)$; (T3) intercropping with Mungbean variety (N-26); (T4) inorganic fertilizer (at $41 \mathrm{~kg} \mathrm{~N} \mathrm{ha}^{-1}$ and $46 \mathrm{~kg} \mathrm{P}_{2} \mathrm{O}_{5} \mathrm{ha}^{-}{ }^{-}$); (T5) 50\% compost $+50 \%$ inorganic fertilizer; (T6) 50\% compost + intercropping; (T7) 50\% inorganic fertilizer + intercropping; (T8) 50\% compost + intercropping $+50 \%$ inorganic fertilizer rate; (T9) Striga resistant sorghum. These treatments were laid out in Randomized Complete Block Design (RCBD) with three replications. According to the current results, the maximum average grain yield $\left(4640.40 \mathrm{~kg} \mathrm{ha}^{-1}\right)$ and total biomass $\left(10879.60 \mathrm{~kg} \mathrm{ha}^{-1}\right)$, head weight $(93.54 \mathrm{~g})$, and plant height $(164.16 \mathrm{~cm})$ were recorded prominently in plots treated with inorganic fertilizer. The combination of compost and inorganic fertilizer also gave remarkable grain (4537.80 $\mathrm{kg} \mathrm{ha}^{-1}$ ) and biomass yields (10592.60 kg ha-1). Moreover, Striga population reduced due to application of inorganic fertilizers $\left(0.95\right.$ Striga $\left.\mathrm{m}^{-2}\right)$. A significant reduction was also observed when plots were treated with the combination of compost and inorganic fertilizer $\left(1.17\right.$ Striga $\left.\mathrm{m}^{-2}\right)$. Similarly, as compared to farmers' practice (2.37 Striga $\mathrm{m}^{-2}$ ), low number of Striga $\mathrm{m}^{-2}(1.24)$ was recorded from resistant sorghum variety (Gubiye). Based on economic analysis, application of 50\% compost $+50 \%$ inorganic fertilizers gave optimum marginal rate of return (MRR) (165.66\%), which was above the minimum rate of return $(100 \%)$. Generally, this experiment showed that productivity of sorghum is considerably higher when farmers use integrated soil fertility management options. This is, therefore, integrated use of 50\% compost and 50\% inorganic fertilizers should be recommended for farmers as they were affordable options for increasing sorghum yields with improving soil fertility in the small-scale farming systems of the study area. Furthermore, integrated use of organic and inorganic fertilizers proved to be highly effective in terms of reducing Striga incidence both in terms of reduced seed density in the soil and decreased infection in sorghum.
\end{abstract}

Keywords: Agronomic practices, Sorghum, Striga, Yield, Yield components

DOI: $10.7176 / J N S R / 10-1-04$

Publication date: January $31^{\text {st }} 2020$

\section{INTRODUCTION}

In Ethiopia, the genus Striga (Orobanchaceae) is the most important biotic constraint affecting sorghum production. Striga hermonthica (Del.) Benth (Scrophulariacae), which is among Striga weed spp. competes for water and nutrients as a root parasite, is one of the major production constraints in the subsistence agriculture regions of Ethiopia. The problem in those areas is aggravated by the inherent low soil fertility, recurrent drought and overall natural resource degradation because of decades of continuous cereal monoculture and deforestation (Fasil, 2002). The Striga problem in sub-sharan Africa is exasperated by its exquisite adaptation to the climatic conditions of the Semi-Arid tropics, its high fecundity, and longevity of its seed reserves in tropical soils (Kudra et al., 2012). This is, therefore, reducing the seed bank from the infested field must be considered as one strategy for effective control.

The crop plants which stimulate germination and do not support the seedling further for establishment are known as false hosts (trap crops). Crop rotation and intercropping with these false hosts are of practical importance in reducing the Striga seed reserves from the soil. Thus conducting simultaneous experiments to determine effective inter crop or tap crop with proper dose determination of $\mathrm{N}$ and compost rates seems to be a reasonable idea for better controlling measure, as fertility improvement is considered as a control (Chikoye et al., 2006; Mumera and Below, 1993; Kim et al., 1997). A work of Chikoye et al. (2006), conducted in Kenya, indicated that maize vigor and grain yield were lowest where no $\mathrm{N}$ was applied and increased with higher $\mathrm{N}$ rates. On the other hand, Striga incidence and crop damage were higher where no N was applied and decreased with higher $\mathrm{N}$ rates. 
From the point of economic analysis, these authors generalized that the use of Striga tolerant maize and legume trap crops grown in rotation with maize can provide better returns than continuous maize.

In general, to alleviate yield loss due to Striga infestation and to have optimum crop productivity and to ensure food self sufficiency in the study area, agricultural research activities should focus on integrated agronomic Striga control as sustainable control of Striga through single control options is unlikely (Schulz et al., 2003). Therefore, this research studywas initiated to evaluate each agronomic practices on Striga controlling management and to determine the most effective agronomic practices on sorghum crop yield

\section{MATERIALS AND METHODS}

The experiment was carried out under rain fed conditions in 2015 and 2016 cropping seasons in Alamata woreda which is situated at $12^{\circ} 15^{\prime} \mathrm{N}$ latitude and $39^{\circ} 35^{\prime} \mathrm{E}$ longitude. The area is found at an altitude of 1450 to 1750 meter above sea level (m.a.s.l) with average annual rain fall of $663 \mathrm{~mm}$ and mean annual temperature of $14.6^{\circ} \mathrm{c}$ to $29.7^{\circ} \mathrm{c}$ (Abay, 2013).The treatments were laid out under RCB design with three replications. Improved sorghum variety (Meko-I) adapted to the area was used. The treatments (T) were (T1) farmers' practice (no fertilizer and intercropping) as a control; (T2) compost (at 10 ton ha ${ }^{-1}$ ); (T3) intercropping with Mungbean variety (N-26) at seed rate of $20 \mathrm{~kg}$ $\mathrm{ha}^{-1}$; (T4) inorganic fertilizer (at $41 \mathrm{~kg} \mathrm{~N} \mathrm{ha}^{-1}$ and $46 \mathrm{~kg} \mathrm{P}_{2} \mathrm{O}_{5}$ ha- $^{-1}$ ); (T5) 50\% compost $+50 \%$ inorganic fertilizer; (T6) 50\% compost + intercropping; (T7) 50\% inorganic fertilizer + intercropping; (T8) 50\% compost + intercropping $+50 \%$ inorganic fertilizer rate; (T9) Striga resistant sorghum (Gubiye variety). Meko-I sorghum variety was planted in a plot size of $3.75 \mathrm{~m} * 4 \mathrm{~m}\left(15 \mathrm{~m}^{2}\right)$ with five rows at spacing of $75 \mathrm{~cm}$ between rows and $20 \mathrm{~cm}$ between plants within a row. Half dose of Nitrogen in the form of urea was applied during planting while the remained 50\% urea was applied at knee height. Full dose of phosphorus was applied as band application method in the form of Di Ammonium Phosphate (DAP) at planting time. Compost was applied to the plots and mixed with the soil two weeks before planting. Intercropping of Mungbean was done simultaneously with sorghum at 1:1 planting pattern. Ridge on all plots to harvest water was made to be of $0.30 \mathrm{~m}$ in height and the ties were at a height of $0.25 \mathrm{~m}$. All other appropriate agronomic practices such as weeding excluding Striga weed and thinning were conducted uniformly to the experimental field.

Agronomic data on days to $90 \%$ maturity, plant height $(\mathrm{cm})$, panicle length $(\mathrm{cm})$, grain yield $\left(\mathrm{kg} \mathrm{ha}^{-1}\right)$, dry biomass yield $\left(\mathrm{kg} \mathrm{ha}^{-1}\right)$ and number of Striga $\mathrm{m}^{-2}$ were collected. The collected agronomic data were subjected to the analysis of variance (ANOVA) using the SAS software computer package version 9.0 (SAS Institute, 2002) and least significant difference (LSD) at 5\% probability level was employed to compute significance difference among the treatment means (Gomez and Gomez, 1984).

Economic analysis was also performed to investigate the economic feasibility of the treatments by using partial and marginal analyses. Marginal rate of return (MRR) was calculated as the change in net benefit (NB) divided by the change in total variable cost (TVC) of the successive net benefit and total variable cost levels (CIMMYT, 1988). Total variable cost was calculated from purchasing costs of DAP, urea, and Mungbean seed but not cost of sorghum varieties as it was the same cost. It also included the labor costs. Labor costs to manage the treatments (compost preparation, planting, fertilizer application, weeding, harvesting and threshing) were calculated by using 50 ETB per person per day. The price of DAP, urea, and Mungbean seed was 1563.20 ETB $100 \mathrm{~kg}^{-1}, 1057.35 \mathrm{ETB} 100 \mathrm{~kg}^{-1}$, and $15 \mathrm{ETB} \mathrm{kg}$, , respectively. The cost of compost was only consider the wage for preparation of compost because compost was prepared by using local available materials in the area. In the economic analysis, the average yields were adjusted down wards by $10 \%$, taking in to consideration those farmers could obtain $10 \%$ less than the experiment yield (CIMMYT, 1998).

\section{RESULTS AND DISCUSSION Days to maturity}

As shown in Table 1, days to maturity was highly significantly $(\mathrm{P}<0.01)$ influenced in 2015 and also significantly $(\mathrm{P}<0.05)$ affected in 2016 cropping seasons. According to this current finding, Gubiye sorghum variety was late mature crop, which took 101.83 to 110 days, as compared to Meko-I. It matured in a range of 98.17 to 107.33 days. Earliness or lateness in the days to maturity might have been due to their inherited characters, early acclimatization to the growing area to enhance their growth and developments. Unlike to Gubiye and intercropping $+50 \%$ inorganic fertilizer, the other treatments were significantly at par with control in the year 2015. Similarly, without Gubiye, compost and 50\% compost $+50 \%$ inorganic fertilizer treatments, the other agronomic practices were similarly affecting days to maturity of Meko-I variety in 2016 cropping season. This present finding was in agreement with the work of Zerihun (2016) who reported that days to $90 \%$ physiological maturity was significantly different due to nitrogen and variety. He noted that high level of $\mathrm{N}$ delays maturity as it increases vegetative growth and difference in days to maturity of the varieties ascribed to their genetic characteristics. 
Table 1. Effect of Striga controlling management practices on days to maturity of sorghum

\begin{tabular}{|c|c|c|c|}
\hline \multirow[t]{2}{*}{ Treatments } & \multicolumn{3}{|c|}{ Days to maturity } \\
\hline & Year_1 & Year_2 & Mean \\
\hline Control /no fertilizer/ & $98.17 \mathrm{c}$ & $105.00 \mathrm{c}$ & 101.59 \\
\hline Compost & $98.50 \mathrm{bc}$ & $107.33 \mathrm{~b}$ & 102.92 \\
\hline Intercropping & $99.00 \mathrm{bc}$ & $106.67 \mathrm{bc}$ & 102.84 \\
\hline Inorganic fertilizer & $98.50 \mathrm{bc}$ & $107.00 \mathrm{bc}$ & 102.75 \\
\hline $50 \%$ compost $+50 \%$ inorganic fertilizer & $99.00 \mathrm{bc}$ & $107.33 b$ & 103.16 \\
\hline $50 \%$ compost + intercropping & $99.00 \mathrm{bc}$ & $106.00 \mathrm{bc}$ & 102.5 \\
\hline Intercropping $+50 \%$ inorganic fertilizer & $99.33 b$ & $107.00 \mathrm{bc}$ & 103.16 \\
\hline $50 \%$ compost + intercropping $+50 \%$ inorganic fertilizer rate & $98.83 \mathrm{bc}$ & $106.67 \mathrm{bc}$ & 102.75 \\
\hline Resistant sorghum crop (Gubiye) & $101.83 \mathrm{a}$ & $110.00 \mathrm{a}$ & 105.92 \\
\hline $\mathrm{CV}(\%)$ & 0.61 & 1.25 & \\
\hline LSD (0.05) & 1.05 & 2.32 & \\
\hline
\end{tabular}

Means with the same letter ( $\mathrm{s}$ ) in the same column are not significantly different at $\mathrm{P}<0.05$ and $\mathrm{P}<0.01 ; \mathrm{LSD}=$ least significant difference; $C V=$ coefficient of variance; Year_1 $=2015$; Year_2 $=2016$

Panicle length

Panicle length was differed significantly $(\mathrm{P}<0.01)$ due to the effect of integrated agronomic practices in 2015 cropping season (Table 2). The maximum value $(24.17 \mathrm{~cm})$ was recorded from Gubiye while the minimum panicle length $(19.17 \mathrm{~cm})$ was from the control. As revealed in this table, similar trend was happened in 2016. Accordingly, Gubiye registered significantly $(\mathrm{P}<0.05)$ higher panicle length $(26.60 \mathrm{~cm})$ in contrast to the other treatments. It was generally noted that Gubiye gave high panicle length while Meko-I produced smaller value. Gubiye variety had $19.66 \%$ to $26.08 \%$ taller panicle length than Meko-I. This difference could be most probably due to their inherited traits and adaptability to the environmental condition of the study area. This current result was supported by the findings of Zerihun (2016) who explained that the effect of variety on panicle length of sorghum was significant, where the longest panicle length $(25.74 \mathrm{~cm})$ was recorded from Gubiye among Hormat and Teshale varieties.

Table 2. Mean of plant height and panicle length of sorghum as influenced by Striga controlling management practices

\begin{tabular}{lllllll}
\hline Treatments & \multicolumn{3}{l}{ Plant height $(\mathbf{c m})$} & \multicolumn{3}{l}{ Panicle length (cm) } \\
& Year_1 & Year_2 & Mean & Year_1 & Year_2 & Mean \\
\hline Control /no fertilizer/ & $135.67 \mathrm{~b}$ & $161.00 \mathrm{ab}$ & 148.33 & $19.17 \mathrm{c}$ & $22.23 \mathrm{~b}$ & 20.70 \\
Compost rate & $152.83 \mathrm{a}$ & $166.27 \mathrm{ab}$ & 159.55 & $21.17 \mathrm{~b}$ & $22.87 \mathrm{~b}$ & 22.02 \\
Intercropping & $151.17 \mathrm{ab}$ & $146.93 \mathrm{bc}$ & 149.05 & $20.17 \mathrm{bc}$ & $23.13 \mathrm{~b}$ & 21.65 \\
Inorganic fertilizer & $157.00 \mathrm{a}$ & $171.33 \mathrm{a}$ & 164.16 & $22.00 \mathrm{~b}$ & $23.07 \mathrm{~b}$ & 22.54 \\
50\%compost+50\% inorganic fertilizer & $156.67 \mathrm{a}$ & $173.93 \mathrm{a}$ & 165.30 & $21.83 \mathrm{~b}$ & $23.80 \mathrm{~b}$ & 22.82 \\
50\%compost +intercropping & $152.83 \mathrm{a}$ & $166.27 \mathrm{ab}$ & 159.55 & $20.17 \mathrm{bc}$ & $23.33 \mathrm{~b}$ & 21.75 \\
Intercropping+50\% inorganic fertilizer & $154.83 \mathrm{a}$ & $168.40 \mathrm{a}$ & 161.62 & $20.33 \mathrm{bc}$ & $23.67 \mathrm{~b}$ & 22.00 \\
50\%compost+intercropping+50\%inorganic & $156.67 \mathrm{a}$ & $168.93 \mathrm{a}$ & 162.80 & $20.50 \mathrm{bc}$ & $23.13 \mathrm{~b}$ & 21.82 \\
fertilizer rate & & & & & & \\
Resistant sorghum crop (Gubiye) & $106.00 \mathrm{c}$ & $128.47 \mathrm{c}$ & 117.24 & $24.17 \mathrm{a}$ & $26.60 \mathrm{a}$ & 25.39 \\
\hline CV (\%) & 6.35 & 7.69 & & 5.08 & 5.39 & \\
LSD (0.05) & 16.16 & 21.46 & & 1.85 & 2.20 & \\
\hline
\end{tabular}

Means with the same letter (s) in the same column are not significantly different at $\mathrm{P}<0.05$ and $\mathrm{P}<0.01 ; \mathrm{LSD}=$ least significant difference; $C V=$ coefficient of variance; Year_1=2015; Year 2 $=2016$

Plant height

Agronomic practices showed highly significant difference $(\mathrm{P}<0.01)$ in affecting plant height in both cropping years. In 2015 , the smallest plant height $(106.00 \mathrm{~cm})$ was recorded from Gubiye (Table 2). The other agronomic treatments were statistically at par, which they produced significantly higher plant height as compared to the control. Similar trend is also observed in 2016 where the minimum value $(128.47 \mathrm{~m})$ was obtained from Gubiye while the maximum was due to the other treatments excluding intercropping. Generally, Meko-I was taller than Gubiye variety. It produced a plant height advantage of $25.32 \%$ to $48.11 \%$ over Gubiye. This was ascribed to the difference in genetic make-up of the varieties, and its efficient utilization of environmental growth resources so as to stimulate and enhance the photosynthetic and metabolic activities of the plant which reflected on the increase in the vegetative growth of Meko-I. This result was in conformity with the findings of Adekayode and Ogunkoya (2010) who reported significantly higher maize plant height $(197.6 \mathrm{~cm})$ in $300 \mathrm{~kg} \mathrm{NPK} \mathrm{ha}^{-1}$ and lower value of $167.9 \mathrm{~cm}$ in plots without fertilizer $\left(0 \mathrm{~kg} \mathrm{NPK} \mathrm{ha}^{-1}\right)$. 


\section{Grain yield}

Yield of sorghum was highly significantly $(\mathrm{P}<0.01)$ affected by integrated agronomic practices in 2015 . According to Table 4, a prominent grain yield $\left(4669.50 \mathrm{~kg} \mathrm{ha}^{-1}\right)$ was produced due to application of inorganic fertilizer though statistically similar with the effect of compost, intercropping and $50 \%$ compost $+50 \%$ inorganic fertilizer. Conversely, the smallest yield was recorded from Gubiye which gave 34.38 \% to 45.36\% lower yield than MekoI. Similarly, the treatments showed significant difference $(\mathrm{P}<0.05)$ in influencing the grain yield of sorghum in 2016 cropping season (Table 4).

Table 4. Effect of Striga controlling management practices on grain yield of sorghum

\begin{tabular}{|c|c|c|c|}
\hline \multirow[t]{2}{*}{ Treatments } & \multicolumn{3}{|c|}{ Grain yield $\left(\mathrm{kg} \mathrm{ha}^{-1}\right)$} \\
\hline & Year -1 & Year-2 & Mean \\
\hline Control /no fertilizer/ & $3917.67 b c$ & $4043.20 \mathrm{ab}$ & 3980.40 \\
\hline Compost rate & $4042.83 \mathrm{abc}$ & $4354.50 \mathrm{ab}$ & 4198.70 \\
\hline Intercropping (Mungbean) & $4029.50 \mathrm{abc}$ & $4156.80 \mathrm{ab}$ & 4093.20 \\
\hline Inorganic fertilizer & $4669.50 \mathrm{a}$ & $4611.30 \mathrm{a}$ & 4640.40 \\
\hline $50 \%$ compost $+50 \%$ inorganic fertilizer & $4583.17 \mathrm{ab}$ & $4492.40 \mathrm{ab}$ & 4537.80 \\
\hline $50 \%$ compost + intercropping(Mungbean) & $3940.17 b c$ & $3740.50 \mathrm{~b}$ & 3840.30 \\
\hline Intercropping(Mungbean) $+50 \%$ inorganic fertilizer & $3924.33 b c$ & $4000.30 \mathrm{ab}$ & 3962.30 \\
\hline $50 \%$ compost + intercropping $+50 \%$ inorganic fertilizer rate & $3887.83 \mathrm{c}$ & $4355.90 \mathrm{ab}$ & 4121.80 \\
\hline Resistant sorghum crop /Gubiye/ & $2551.17 \mathrm{~d}$ & $2882.30 \mathrm{c}$ & 2716.70 \\
\hline CV $(\%)$ & 10.04 & 11.53 & \\
\hline $\operatorname{LSD}(0.05)$ & 686.12 & 812.48 & \\
\hline
\end{tabular}

Means with the same letter ( $\mathrm{s}$ ) in the same column are not significantly different at $\mathrm{P}<0.05$ and $\mathrm{P}<0.01 ; \mathrm{LSD}=$ least significant difference; $C V=$ coefficient of variance; Year_1=2015; Year_2 $=2016$

Like to in 2015 , the smallest yield $\left(2882.30 \mathrm{~kg} \mathrm{ha}^{-1}\right)$ was achieved from resistant (Gubiye) sorghum variety while the maximum yield (4611.30 $\left.\mathrm{kg} \mathrm{ha}^{-1}\right)$ was obtained from application of inorganic fertilizer which was significantly at par with the other treatments excluding use of 50\%compost + intercropping and resistant sorghum crop. This yield increment could be attributed to the direct response of $\mathrm{N}$ on stimulation of plants growth which in turn reflected on grain yield production, and the role of compost in improving cation exchange capacity (CEC), aeration, root penetration, water storage capacity of the soil as well as being host of different microbes. This was supported by the report of Habtamu et al. (2015). In addition, other findings confirmed that application of high $\mathrm{N}$ fertilizer (120 kg N ha ${ }^{-1}$ ) enhanced grain yield, and 1000 grain weight of maize (Miao et al., 2007). Moreover, the result of this experiment was coherent with previous research results of Dilshad et al. (2010); Nivong et al. (2007) noted that combined use of organic and inorganic fertilizers improved grain yield of maize.

\section{Biomass yield}

Table 5 revealed that biomass yield was significantly $(\mathrm{P}<0.05)$ affected by the treatments in the year of 2015 . According to this mean result table (Table 5), the highest value $\left(10722.10 \mathrm{~kg} \mathrm{ha}^{-1}\right)$ was obtained due inorganic fertilizers which, however, significantly similar with use of $50 \%$ compost $+50 \%$ inorganic fertilizer. Equally important, biomass yield was highly significantly $(\mathrm{P}<0.01)$ influenced by the integrated agronomic practices in 2016. The highest mean numeric value $\left(11037.00 \mathrm{~kg} \mathrm{ha}^{-1}\right)$ was also produced from application of inorganic fertilizer.

Table 5. Mean values of biomass yield of sorghum as influenced by agronomic Striga management practices

\begin{tabular}{llll}
\hline Treatments & \multicolumn{2}{c}{ Biomass yield $\left(\mathbf{k g ~ h a}^{-\mathbf{1}}\right)$} & Mean \\
\hline Control /no fertilizer/ & Year-1 & Year-2 & 8368.20 \\
Compost rate & $8291.90 \mathrm{c}$ & $8444.40 \mathrm{~d}$ & 8209.00 \\
Intercropping & $8875.00 \mathrm{bc}$ & $9543.00 \mathrm{bcd}$ & 92.80 \\
Inorganic fertilizer & $8472.30 \mathrm{c}$ & $8733.30 \mathrm{~cd}$ & 8602.80 \\
$50 \%$ compost+50\%inorganic fertilizer & $10722.10 \mathrm{a}$ & $11037.00 \mathrm{a}$ & 10879.60 \\
$50 \%$ compost+intercropping & $10333.40 \mathrm{ab}$ & $10851.90 \mathrm{ab}$ & 10592.60 \\
Intercropping +50\%inorganic fertilizer & $8597.40 \mathrm{c}$ & $9518.50 \mathrm{bcd}$ & 9057.90 \\
$50 \%$ compost+intercropping+50\%inorganic fertilizer rate & $8523.80 \mathrm{c}$ & $10629.60 \mathrm{ab}$ & 9576.70 \\
Resistant sorghum (Gubiye) crop & $8555.50 \mathrm{c}$ & $10111.10 \mathrm{abc}$ & 9333.30 \\
\hline CV $(\%)$ & $8616.80 \mathrm{c}$ & $8629.60 \mathrm{~d}$ & 8623.20 \\
LSD $(0.5)$ & 9.92 & 8.60 & \\
\hline
\end{tabular}

Means with the same letter (s) in the same column are not significantly different at $\mathrm{P}<0.05$ and $\mathrm{P}<0.01 ; \mathrm{LSD}=$ least significant difference; $\mathrm{CV}=$ coefficient of variance; Year 1=2015; Year 2 $=2016$

This might be ascribed to the vital role of $\mathrm{N}$ in exciting and enhancing the photosynthetic and metabolic activities of plants which reflected on the increase in the vegetative growth of sorghum. High $\mathrm{N}$ fertilizer 
application could improve the growth and above ground biomass production of sorghum crop. This complemented to the work of Wondimu et al. (2006) who reported that farmyard manure and inorganic fertilizers increased stover yield of sorghum by $8 \%$ to $21 \%$ and $14 \%$ to $21 \%$, respectively. Furthermore, the present result was consistent with the findings of Kibunja et al. (2010) which showed total dry matter of maize was higher in treatment combinations of inorganic and organic fertilizers.

Number of Striga $\mathbf{~ m}^{-2}$

Striga population was significantly $(\mathrm{P}<0.05)$ varied by agronomic Striga management practices in 2015 cropping season. According to Table 6, more number of Striga $\mathrm{m}^{-2}$ (1.78) existed in the farmers' practice (control) while the minimum Striga population was observed from plots treated with inorganic fertilizer which produced $46.07 \%$ less number of Striga $\mathrm{m}^{-2}$ as compared to the control. This was significantly similar with plots treated with $50 \%$ compost $+50 \%$ inorganic fertilizer, and 50\%compost + intercropping $+50 \%$ inorganic fertilizer. Resistant sorghum variety (Gubiye), like inorganic fertilizer, was also producing significantly similar number of Striga $\mathrm{m}^{-2}$. Table 6 also showed that agronomic Striga management practices resulted highly significant $(\mathrm{P}<0.01)$ effect on number of Striga $\mathrm{m}^{-2}$ in 2016. Maximum number of Striga $\mathrm{m}^{-2}$ (2.96) was recorded from the control while minimum mean Striga population (0.95) grew on plots treated with inorganic fertilizer. Similar to inorganic fertilizer, plots treated with $50 \%$ compost $+50 \%$ inorganic fertilizer as well as resistant sorghum crop gave significantly similar Striga population. This significant variation might be ascribed to the effect of fertilizers in suppressing growth of Striga weed and low germination stimulant production by Gubiye which inhibit germination of Striga seed in the absence of chemical stimulant.This current result was in lined with the findings of Zerihun (2016) which indicated that number of S.hermonthica per plot was significantly influenced by N fertilizer, variety and their interaction. The author specified that low number of Striga registered from plots treated with high N level and Striga resistant sorghum variety (Gubiye). A report of Hassan et al. (2010) illustrated that Nitrogen inhibited to Striga growth which reduced Striga infestation by $83 \%$. In addition, Hassan et al. (2010) and Kudra et al. (2014) found thatcombination of chicken manure with nitrogen as urea is an effective weed management practice to control Striga. Generally, use of recommended cropping systems and plant populations, Striga resistant sorghum varieties, improved soil fertility and soil moisture conservation practices help to maximize crop vigor and minimize effects of Striga (Mgonja et al., 2011).

Table 6. Mean number of Strigam ${ }^{-2}$ as influenced by agronomic Striga management practices

\begin{tabular}{llll}
\hline Treatments & \multicolumn{2}{l}{ Number of Strigam } & \\
& Year-1 & Year-2 & Mean \\
\hline Control /no fertilizer/ & $1.78 \mathrm{a}$ & $2.96 \mathrm{a}$ & 2.37 \\
Compost rate & $1.41 \mathrm{abc}$ & $2.76 \mathrm{ab}$ & 2.08 \\
Intercropping(Mungbean) & $1.44 \mathrm{abc}$ & $2.52 \mathrm{ab}$ & 1.98 \\
Inorganic fertilizer & $0.96 \mathrm{~d}$ & $0.95 \mathrm{~d}$ & 0.95 \\
$50 \%$ compost+50\%inorganic fertilizer & $1.07 \mathrm{~cd}$ & $1.26 \mathrm{~cd}$ & 1.17 \\
$50 \%$ compost+intercropping (Mungbean) & $1.44 \mathrm{abc}$ & $2.48 \mathrm{ab}$ & 1.96 \\
Intercropping(Mungbean)+50\%inorganic fertilizer & $1.56 \mathrm{ab}$ & $2.00 \mathrm{bc}$ & 1.78 \\
$50 \%$ compost+intercropping+50\%inorganic fertilizer & $1.21 \mathrm{bcd}$ & $2.17 \mathrm{ab}$ & 1.69 \\
Resistant sorghum crop (Gubiye) & $1.23 \mathrm{bcd}$ & $1.26 \mathrm{~cd}$ & 1.24 \\
CV $(\%)$ & 19.26 & 23.74 & \\
LSD $(0.5)$ & 0.45 & 0.84 & \\
\hline
\end{tabular}

Means with the same letter (s) in the same column are not significantly different at $\mathrm{P}<0.05$ and $\mathrm{P}<0.01 ; \mathrm{LSD}=$ least significant difference; $\mathrm{CV}=$ coefficient of variance; Year_1=2015; Year_2 $=2016$

Economic analysis

Based on economic analysis, application of $50 \%$ compost $+50 \%$ inorganic fertilizers gave optimum MRR $(165.66 \%)$ which was above the minimum rate of return $(100 \%)$ (Table 6). This economic analysis was decided mainly on sustainability of soil health, and the increasing cost of inorganic fertilizers. Furthermore, poor farmers could not afford the cost for full rate of inorganic fertilizer. Thus, integrated use of organic (compost) and inorganic fertilizers is economically feasible to sustain the productivity of sorghum. According to this analysis, for farmers who use $50 \%$ compost $+50 \%$ inorganic fertilizer, investing in the higher fertilizer rate would give a marginal rate of return of $165.66 \%$; for every $\$ 1$. OO invested in the higher fertilizer rate, they will recover the $\$ 1.00$ and an additional $\$ 1.6566$. 
Table 6. Marginal budget analysis of sorghum as affected by integrated agronomic practices

\begin{tabular}{|c|c|c|c|c|c|c|c|c|}
\hline \multirow[t]{2}{*}{ Treatments } & \multicolumn{2}{|c|}{$\begin{array}{l}\text { Adjusted } \\
\text { Yield } \\
\left(\mathrm{Kg} \mathrm{ha}^{-1}\right)\end{array}$} & \multicolumn{2}{|c|}{$\begin{array}{l}\text { Income } \\
\left(\text { ETB ha }{ }^{-1}\right)\end{array}$} & \multirow{2}{*}{$\begin{array}{l}\text { Gross } \\
\text { field } \\
\text { benefit } \\
\text { s } \\
(\text { ETB } \\
\left.\text { ha }^{-1}\right)\end{array}$} & \multirow[t]{2}{*}{$\begin{array}{l}\text { TVC } \\
(\text { ETB } \\
\left.\text { ha }^{-1}\right)\end{array}$} & \multirow{2}{*}{$\begin{array}{l}\text { Net } \\
\text { incom } \\
\text { e } \\
(\text { ETB } \\
\left.\text { ha }^{-1}\right)\end{array}$} & \multirow[t]{2}{*}{$\begin{array}{l}\text { MR } \\
\text { R } \\
(\%)\end{array}$} \\
\hline & GY & BY & GY & BY & & & & \\
\hline Control /no fertilizer/ & $\begin{array}{l}3638 . \\
88\end{array}$ & $\begin{array}{l}7599 . \\
96\end{array}$ & $\begin{array}{l}32749 . \\
92\end{array}$ & $\begin{array}{l}3419 . \\
98\end{array}$ & $\begin{array}{l}36169 . \\
90\end{array}$ & $\begin{array}{l}3537 . \\
77\end{array}$ & $\begin{array}{c}32632 . \\
13\end{array}$ & - \\
\hline Resistant sorghum & $\begin{array}{l}2594 . \\
07\end{array}$ & $\begin{array}{l}7766 . \\
64\end{array}$ & $\begin{array}{l}23346 . \\
63\end{array}$ & $\begin{array}{l}3494 . \\
99\end{array}$ & $\begin{array}{l}26841 \\
62\end{array}$ & $\begin{array}{l}3740 . \\
00\end{array}$ & $\begin{array}{c}23101 \\
62\end{array}$ & $\mathrm{D}$ \\
\hline Compost rate & $\begin{array}{l}3919 . \\
05\end{array}$ & $\begin{array}{l}8588 . \\
70\end{array}$ & $\begin{array}{l}35271 \\
45\end{array}$ & $\begin{array}{l}3864 . \\
92\end{array}$ & $\begin{array}{l}39136 . \\
37\end{array}$ & $\begin{array}{l}4726 . \\
67\end{array}$ & $\begin{array}{c}34409 \\
70\end{array}$ & $\begin{array}{c}197 . \\
67\end{array}$ \\
\hline $\begin{array}{l}50 \% \text { compost }+50 \% \text { inorganic } \\
\text { fertilizer }\end{array}$ & $\begin{array}{l}4043 . \\
16\end{array}$ & $\begin{array}{l}9766 . \\
71\end{array}$ & $\begin{array}{l}36388 \\
44\end{array}$ & $\begin{array}{l}4395 . \\
02\end{array}$ & $\begin{array}{l}40783 . \\
46\end{array}$ & $\begin{array}{l}5280 \\
00\end{array}$ & $\begin{array}{c}35503 . \\
46\end{array}$ & $\begin{array}{c}165 . \\
66\end{array}$ \\
\hline Inorganic fertilizer & $\begin{array}{l}4150 . \\
17\end{array}$ & $\begin{array}{l}9933 . \\
30\end{array}$ & $\begin{array}{l}37351 . \\
53\end{array}$ & $\begin{array}{l}4469 . \\
93\end{array}$ & $\begin{array}{l}41821 . \\
46\end{array}$ & $\begin{array}{l}5451 . \\
11\end{array}$ & $\begin{array}{l}36370 \\
35\end{array}$ & $\begin{array}{c}506 . \\
63\end{array}$ \\
\hline Intercropping & $\begin{array}{l}3741 . \\
12\end{array}$ & $\begin{array}{l}7859 . \\
97\end{array}$ & $\begin{array}{l}39535 . \\
74\end{array}$ & $\begin{array}{l}4217 . \\
42\end{array}$ & $\begin{array}{l}43753 . \\
16\end{array}$ & $\begin{array}{l}7260 . \\
00\end{array}$ & $\begin{array}{c}36493 . \\
16\end{array}$ & 6.79 \\
\hline $\begin{array}{l}50 \% \text { compost }+ \text { intercropping } \\
\text { (Mungbean) }\end{array}$ & $\begin{array}{l}3366 . \\
45\end{array}$ & $\begin{array}{l}8566 . \\
65\end{array}$ & $\begin{array}{l}36213 \\
21\end{array}$ & $\begin{array}{l}4587 . \\
67\end{array}$ & $\begin{array}{l}40800 . \\
88\end{array}$ & $\begin{array}{l}8320 . \\
00\end{array}$ & $\begin{array}{c}32480 . \\
88\end{array}$ & $\mathrm{D}$ \\
\hline $\begin{array}{l}\text { Intercropping }+50 \% \text { inorganic } \\
\text { fertilizer }\end{array}$ & $\begin{array}{l}3600 . \\
27\end{array}$ & $\begin{array}{l}9566 . \\
64\end{array}$ & $\begin{array}{l}39374 . \\
91\end{array}$ & $\begin{array}{l}5076 . \\
99\end{array}$ & $\begin{array}{l}44451 . \\
90\end{array}$ & $\begin{array}{l}8533 . \\
33\end{array}$ & $\begin{array}{c}35918 . \\
57\end{array}$ & $\mathrm{D}$ \\
\hline $\begin{array}{l}50 \% \text { compost }+ \text { intercropping }+50 \% \mathrm{i} \\
\text { norganic fertilizer }\end{array}$ & $\begin{array}{l}3920 . \\
31\end{array}$ & $\begin{array}{l}9099 . \\
99\end{array}$ & $\begin{array}{l}41321 . \\
25\end{array}$ & $\begin{array}{l}4859 . \\
34\end{array}$ & $\begin{array}{l}46180 . \\
59\end{array}$ & $\begin{array}{l}9440 . \\
00\end{array}$ & $\begin{array}{c}36740 . \\
59\end{array}$ & 5.98 \\
\hline
\end{tabular}

Grain price of sorghum $=$ ETB $9 \mathrm{~kg}^{-1}$; Biomass yield of sorghum $=$ ETB $0.45 \mathrm{~kg}^{-1}$; Seed price of Mungbean $=$ ETB $18 \mathrm{~kg}^{-1}$; Biomass yield of Mungbean $=\mathrm{ETB} 0.45 \mathrm{~kg}^{-1} ; \mathrm{MRR}=$ marginal rate of return; ETB = Ethiopian birr; $\mathrm{GY}=$ grain yield, $\mathrm{BY}=$ biomass yield; $\mathrm{TVC}=$ total variable cost; $\mathrm{D}=$ dominated treatment; Average grain yield of Mungbean variety was $362.08 \mathrm{~kg} \mathrm{ha}^{-1}, 365.13 \mathrm{~kg} \mathrm{ha}^{-1}, 430.40 \mathrm{~kg} \mathrm{ha}^{-1}$ and $372.75 \mathrm{~kg} \mathrm{ha}^{-1}$ at (T3), (T6), (T7) and (T8), respectively. Similarly, average biomass yield of Mungbean variety was $1680.08 \mathrm{~kg} \mathrm{ha}^{-1}, 1809.07 \mathrm{~kg} \mathrm{ha}^{-1}$, 1906.17 $\mathrm{kg} \mathrm{ha}^{-1}$ and $1887.28 \mathrm{~kg} \mathrm{ha}^{-1}$ at (T3), (T6), (T7) and (T8), respectively;

Minimum rate of return $=100 \%$

\section{Conclusions}

The maximum grain yield and yield components of total biomass, head weight, and plant height were recorded prominently in plots treated with inorganic fertilizer. The combination of compost and inorganic fertilizer also gave remarkable grain and biomass yields. Moreover, Striga population reduced due application of inorganic fertilizers. A significant reduction was also observed when plots treated with the combination of compost and inorganic fertilizer. Similarly, low number of Striga $\mathrm{m}^{-2}$ was recorded from resistant sorghum variety (Gubiye) which characterized by low germination stimulant (LGS) production, low production of the haustorial initiation factor and its incompatible response to parasitic invasion. Based on economic analysis, application of $50 \%$ compost $+50 \%$ inorganic fertilizers gave optimum MRR, which was above the minimum rate of return $(100 \%)$. Thus, the use of integrated organic and inorganic fertilizers is economically feasible. Generally, this experiment showed that productivity of sorghum is considerably higher when farmers use integrated soil fertility management options. This is, therefore, the use of integrated compost and inorganic fertilizers should be recommended for farmers as they were affordable options for increasing sorghum yields with improving soil fertility in the smallscale farming systems of the study area. Furthermore, integrated agronomic control practices proved to be highly effective in terms of reducing Striga incidence both in terms of reduced seed density in the soil and decreased infection in sorghum.

\section{REFERENCES}

Abay, T., 2013. Factors Affecting Forest User's Participation in Participatory Forest Management; Evidence from Alamata Community Forest, Tigray; Ethiopia.M.Sc. Thesis, Mekelle University, Mekelle, Ethiopia.

Adekayode, F.O. and Ogunkoya, M.O., 2010. Effect of quantity and placement distances of inorganic 15-15-15 fertilizer in improving soil fertility status and the performance and yield of maize in a tropical rain forest zone of Nigeria. J. Soil. Sci. Environ. Manage., 1: 155-163.

Chikoye, D., Ellis-Jones, J., Tarawali, G., and Lum, A.F (Editors)., 2006. Reducing Poverty through Improved Striga Control. Proceedings of the second Striga management stakeholders' conference, 8-9 September 2004, Zaria, Kaduna State.IITA, Ibadan, Nigeria.120 pages. 
CIMMYT, 1988. From Agronomic Data to Farmer Recommendations: An Economics Training Manual. Completely revised edition, Mexico. D.F conference held at International Livestock Centre for Africa (ILCA), 31 August - 4 September 1987

Dilshad, M.D., Lone, M.I. „Jilani, G. , Malik, M.A. , Yousaf, M. , Khalid, R. and Shamim, F., 2010. Integrated Plant Nutrient Management (IPNM) on maize under rainfed condition. Pak. J. Nutr., 9: 896-901.

Fasil, R., 2002. Striga hermonthica in Tigray (Northern Ethiopia). Prospects for control and improvement of productivity through mixed cropping. Ethiopia Agricultural Research Organization, Addis Ababa, Ethiopia. $118 \mathrm{p}$.

Gomez, K.A. and Gomez, A.A., 1984. Statistical procedures for agricultural research, $2^{\text {nd }}$ edition. John Viley and Sons Inc., New York.

Habtamu, A., Heluf, G., Bobe, B. and Enyew, A., 2015. Effects of Organic and Inorganic Fertilizers on Yield and Yield Components of Maize at Wujiraba Watershed, Northwestern Highlands of Ethiopia. American Journal of Plant Nutrition and Fertilization Technology, 5: 1-15.

Hassan, M.M., Yagoub, S.O., Gabouch, N.A., 2010. Effect of different levels of organic manure on Striga hermonthica (Del.) Benth. and sorghum growth. Bioscience Research, 7(1): 32-38

Kibunja, C.N., Mwaura, F.B., Mugendi, D.N. , Kitonyo, E.M. and Salema, M.P., 2010. Nitrogen (N) use efficiency under continuous maize-bean cropping system in semi-humid highlands of Kenya. East Afr. Agric. For. J., 76: $115-120$.

Kim, S.K., Adetimirin, V.O., and Akintunde, A.Y., 1997. Nitrogen effects on Striga hermonthica infestation, grain yield, and agronomic traits of tolerant and susceptible maize hybrids. Crop Science, 37:711-716

Kudra, A., Chemining'wa G.N. and Sibuga K. P., 2014. Striga asiatica growth and seed production in response to organic and inorganic P - fertilizers. Access International Journal of Agricultural sciences, 2(1), 6-12

Kudra, A., Chemining'wa, G.N., Onwonga, R.N., 2012. Relationship between agronomic practices, soil chemical characteristics and Striga reproduction in dryland areas of Tanzania. J. Agric. Sc. Tech., 2:1134-1141.

Mgonja, M. , Audi, P., Manyasa, E. and Ojulong, H., 2011. Integrated Striga Management and Microdosing in Sorghum: A Hope Project Manual for Increasing Sorghum Productivity in Eastern Africa. International Crops Research Institute for Semi Arid Tropics (ICRISAT), P. 1-7.

Miao, Y., Mulla, D.J., Hernandez, J.A., Wiebers, M. and Robert, P.C., 2007. Potential impact of precision nitrogen management on corn yield, protein content and test weight. Soil Sci. Soc. Am. J., 71: 1490-1499.

Mumera, L.M. and Below, F.E., 1993. Role of nitrogen in resistance to Striga parasitism of maize. Crop Science, 33:758-763.

Nivong, S., Attanandana, T. and Yost, R., 2007. Nitrogen fertilizer response of maize on some important soils from DSSAT software prediction. Kasetsart J. (Nat. Sci.), 41: 21-27.

SAS Institute, 2002. SAS/STAT user's guide, version 9.0, SAS Inst., Cary, NC, USA.

Schulz, S., Hussaini, M.A., Kling, J.G., and Berner, D.K., 2003. Evaluation of Integrated Striga hermonthica Control Technologies under Farmer Management. Experimental Agriculture, 39(1): 99-108.

Wondimu, B., Rethman, N.F.G, Hammes, P.S. and Alemu, G., 2006. Effects of Farmyard Manure and Inorganic Fertilizers on Sorghum Growth, Yield, and Nitrogen Use in a Semi-Arid Area of Ethiopia. Journal of Plant Nutrition, 29(2):391-407

Zerihun, S., 2016. Effect of nitrogen fertilizer on striga infestation, yield and yield related traits in sorghum [(Sorghum bicolor (L.) Moench] varieties at Kile, Eastern Ethiopia. Agricultural Science Research Journal, 6(1): $12-26$ 